\title{
AKUNTABILITAS KEUANGAN LEMBAGA FILANTROPI ISLAM DI INDONESIA
}

\author{
Nur Fitriyah \\ Universitas Mataram \\ (nurfitriyah@unram.ac.id) \\ Herlina Pusparini \\ Universitas Mataram \\ (h.pusparini@unram.ac.id) \\ Nurabiah \\ Universitas Mataram \\ (nurabiah@unram.ac.id)*
}

Disubmit: 27 Januari 2021

Mulai Review: 23 Februari 2021

Selesai Review: 22 Mei 2021

Diterima: 7 Juni 2021

\begin{abstract}
Islamic Philanthropic Institutions must report the results of managing zakat, infaq, and alms to gain the trust of the community so that the potential for zakat, infaq, and alms collected is much greater because of the community's trust in these institutions. Therefore this study aims to determine the extent of the level of accountability in the financial transparency of the Islamic Philanthropic Institution in Indonesia as seen based on website data. This type of research is a descriptive study with a quantitative approach. The population in this study were 24 National Islamic Philanthropic Institutions that already have a Registered Certificate (SKT). Determination of the number of samples using the census method. The results of this study state that in terms of accessibility, the national Islamic philanthropy website is very accountable, meaning that the majority of Islamic Philanthropy has a website so that people can access information on Islamic Philanthropy financial statements and in terms of availability of financial reports, there are national Islamic philanthropic websites that are sufficiently accountable, are the statement of financial position and statement of changes in funds and some are less accountable, are statement of changes in managed assets and cash flow statement and there are those that are very less accountable, is notes to financial statements.
\end{abstract}

Keywords: financial accountability, islamic philanthropic institutions

\begin{abstract}
Abstrak
Lembaga Filantropi Islam harus melaporkan hasil pengelolaan zakat, infaq, dan sedekah untuk mendapatkan kepercayaan dari masyarakat sehingga potensi zakat, infaq, dan sedekah yang dikumpulkan jauh lebih besar karena kepercayaan masyarakat terhadap lembaga tersebut. Oleh karena itu penelitian ini bertujuan untuk mengetahui sejauhmana tingkat akuntabilitas dalam tranparansi keuangan Lembaga Filantropi Islam di Indonesia yang dilihat berdasarkan data
\end{abstract}


website. Jenis penelitian yang digunakan adalah penelitian deskriptif dengan pendekatan kuantitatif. Populasi dalam penelitian ini adalah 24 Lembaga Filantropi Islam Nasional yang sudah memiliki Surat Keterangan Terdaftar (SKT). Penentuan jumlah sampel menggunakan metode sensus. Hasil penelitian ini menyatakan bahwa dari segi keteraksesan, website filantropi islam nasional sudah sangat akuntabel, artinya bahwa mayoritas Filantropi Islam memiliki website sehingga masyarakat dapat mengakses informasi laporan keuangan Filantropi Islam tersebut dan dari segi ketersediaan laporan keuangan, website filantropi islam nasional ada yang sudah cukup akuntanbel yaitu laporan posisi keuangan dan laporan perubahan dana dan ada yang kurang akuntabel yaitu laporan perubahan asset dan laporan arus kas dan ada yang sangat kurang akuntabel yaitu catatan atas laporan keuangan.

Kata Kunci: akuntabilitas keuangan, lembaga filantropi islam

\section{PENDAHULUAN}

Berkembangnya filantropi Islam seperti Lembaga Amil Zakat (LAZ), lembaga nazhir wakaf, Badan Amil Zakat Nasional (BAZNAS), dan Badan Wakaf Indonesia (BWI) yang semakin signifikan telah menarik perhatian banyak kalangan. Hal ini wajar karena dalam prakteknya elemen-elemen dari filantropi seperti zakat dan wakaf terbukti bisa membantu mengentaskan kemiskinan masyarakat. Peran filantropi diharapkan bisa memaksimalkan potensi zakat dan mengintegrasikannya ke dalam sistem ekonomi riil. Di Indonesia sendiri, potensi zakat nasional bisa mencapai 3,4\% dari PDB atau sebesar 217 triliun. Hal ini berbanding terbalik dengan pengumpulan dana zakat yang dihimpun yaitu baru $1 \%$ atau sekitar 2,6 triliun. Hal yang sama terjadi pada sektor wakaf yang baru dapat menghimpun dana wakaf 147 miliar dari potensi pertahun 6 triliun (www.baznas.go.id).

Berdasarkan hal ini dapat dilihat bahwa potensi Indonesia dalam pengumpulan dana filantropi islam sangat besar. Tetapi hal ini tidak sesuai dengan pengumpulan dana sosial di Indonesia. Faktor pemahaman masyarakat tentang filantropi islam disebut sebagai faktor utama minimnya pengumpulan ini. Oleh karenanya, dengan banyaknya lembaga filantropi islam di Indonesia haruslah dapat mensosialisasikan nilai-nilai filantropi islam kepada masyarakat dan kepentingannya bagi keadilan sosial. Hal ini diharap dapat menjadi mendorong pengumpulan dana sosial bagi kesejahteraan masyarakat. Dan agar semakin dipercaya oleh masyarakat dan mudah dijangkau oleh kalangan dhuafa maka lembaga Filantropi menjaga kredibilitasnya di depan masyarakat.

Untuk meningkatkan kepercayaan masyarakat terhadap Lembaga Filantropi Islam dibutuhkan tata kelola organisasi yang baik, yaitu terciptanya transparansi dan akuntabilitas. Kusmiati, (2015) mengungkapkan, bahwa "Sebuah institusi dikatakan sehat ketika pengelolaan yang terjadi transparan, akuntabel, birokratif namun tidak kaku, memegang standar baku mutu dan mempunyai kejelasan dalam target dan sasaran mutu yang ingin dicapai. Untuk mewujudkan akuntabilitas sebuah organisasi harus menyuguhkan laporan keuangan zakat, infaq, dan sedeqah secara transparan dan relevan, serta sistem pengelolaan yang yang baik. Dimana Lembaga Filantropi diharapkan dapat menyajikan laporan keuangan zakat sesuai dengan standar yang telah dibuat oleh Ikatan Akuntan Indonesia (IAI) yaitu Pernyataan Standar Akuntansi Keuangan (PSAK) No 109.

Pentingnya akuntabilitas dan transparansi terhadap laporan keuangan Lembaga Filantropi agar mengurangi tindakan korupsi, nepotisme, dan kolusi terhadap dana-dana public. Hal ini sejalan dengan penelitian yang di lakukan oleh Huda, dkk (2014), Nikmatuniayah \& Marliyati (2015), Nurhasanah (2018), Athifah, dkk (2018), Nur Faida (2019) dan Widyawati (2019) yang 
meneliti tentang akuntabilitas laporan keuangan 1 lembaga Islam tetapi dalam penelitian ini meneliti semua di Lembaga Filantropi Islam yang semakin berkembang dan metode yang digunakan adalah deskriptis kuantitatif dengan melihat akuntabilitas dalam transparansi keuangan Lembaga Filantropi di Indonesia melalui website. Selain itu sejalan dengan Shariah Enterprise Theory yang menyatakan bahwa tidak hanya peduli pada kepentingan individu (pemegang saham), tetapi juga pihak-pihak lainnya, dimana SET memiliki kepedulian yang besar pada stakeholders yang luas. Maka SET mengenal tiga stakeholders, yakni Allah, manusia dan alam. Akuntabilitas menurut Triyuwono (2002) merupakan spritualitas akuntansi syari'ah. Konsep akuntabilitas sangat terkait dengan tradisi pemahaman Islam tentang Tuhan, manusia, dan alam semesta (Mulawarman, 2007 : 115). Shariah entarprise theory dengan demikian akan memiliki visi yang lebih luas, yang muncul dalam keluasan cakupan stakeholders perusahaan (Triyuwono, 2002). Didukung juga dengan teori stewardship bahwa manajer akan berperilaku sesuai kepentingan bersama. Ketika kepentingan steward dan pemilik tidak sama, steward akan berusaha bekerja sama dari pada menentangnya, karena steward merasa kepentingan bersama dan berperilaku sesuai dengan perilaku pemilik merupakan pertimbangan yang rasional karena steward lebih melihat pada usaha untuk mencapai tujuan organisasi. Oleh karena itu manajer yang berperan sebagai steward tergerak untuk memenuhi keinginan prinsipal dan tingkat loyalitas terhadap organisasi lebih tinggi sebab steward berusaha untuk mencapai tujuan organisasinya. Pencapaian tujuan organisasi yang maksimal dibutuhkan fungsi akuntansi yang baik. Akuntansi merupakan sarana untuk mengidentifikasi, mencatat kemudian menginformasikan seluruh kegiatan atau transaksi ekonomi dari suatu Lembaga Filantropi Islam.

Tujuan penelitian ini untuk mengetahui sejauhmana tingkat akuntabilitas dalam tranparansi keuangan Lembaga Filantropi Islam di Indonesia yang dilihat berdasarkan data website. Dan urgensi peleitian ini dimana akuntabilitas laporan keuangan Lembaga Filantropi Islam merupakan perwujudan tanggung jawab kepada masyarakat, negara, dan Allah Swt. Oleh karena itu Lembaga Filantropi Islam harus melaporkan hasil pengelolaan zakat, infaq, dan sedekah agar mendapatkan kepercayaan dari masyarakat sehingga potensi zakat, infaq, dan sedekah yang dikumpulkan jauh lebih besar karena kepercayaan masyarakat terhadap lembaga tersebut. Agar kesadaran dan kepercayaan masyarakat dalam berzakat, berinfaq, dan bersedekah ini menjadi semakin tumbuh subur maka dapat diwujudkan melalui kinerja Lembaga Filantropi Islam yang akuntabel, transparan dan profesional. Untuk itu lembaga Filantropi Islam harus memiliki Laporan keuangan yang merupakan cerminan dari pengelolaan keuangan yang baik. Selain itu bisa mengurangi tindakan korupsi, nepotisme, dan kolusi terhadap dana-dana publik sehingga dapat digunakan sebagai rekomendasi bagi Lembaga Filantropi agar memberikan akuntabilitas dalam transparansi laporan keuangan berdasarkan Undang - Undang Nomor 14 Tahun 2008 tentang keterbukaan informasi publik.

Implikasi dari teori stewardship pada penelitian ini bahwasanya manajemen dipandang sebagai pihak yang dapat dipercaya oleh publik untuk melakukan tindakan yang baik dan berguna untuk kepentingan bersama baik secara khusus maupun umum. Stewardship pada penelitian ini adalah manajemen Lembaga Filantropi Islam. Lembaga Filantropi Islam akan bekerja sebaikbaiknya untuk kepentingan masyarkat untuk akuntabel dalam transparansi pelaporan keuangan. Lembaga filantropi islam wajib menyediakan informasi publik yang akurat dan benar seperti memberikan atau menerbitkan informasi mengenai laporan keuangan yang mudah dijangkau oleh masyarakat. 
Fitriyah, Pusparini \& Nurabiah: Akuntabilitas Keuangan Lembaga...

\section{METODE PENELITIAN}

Jenis penelitian yang digunakan adalah penelitian deskriptif dengan pendekatan kuantitatif. Penelitian deskriptif yaitu penelitian yang diarahkan untuk memberikan gejala-gejala, fakta-fakta atau kejadian-kejadian secara sistematis dan akurat mengenai sifat-sifat populasi dan daerah tertentu, dimana akan mengungkapkan fakta-fakta akuntabilitas dalam hal transparansi keuangan di Lembaga Filantropi Islam di Indonesia.

Populasi dalam penelitian ini adalah semua Lembaga Filantropi Islam Nasional yang sudah memiliki Surat Keterangan Terdaftar (SKT) yang berjumlah 23 Lembaga Filantropi Islam. Adapun penentuan jumlah sampel yang digunakan dalam penelitian ini adalah dengan metode sensus. Metode sampling jenuh atau sensus adalah teknik penentuan sampel bila semua anggota populasi digunakan sebagai sampel (Sugiyono, 2017:85), yang dijadikan sampel dalam penelitian ini adalah semua Lembaga Filantropi Islam Nasional yang ada di Indonesia sudah memiliki Surat Keterangan Terdaftar (SKT) berjumlah 23 Lembaga Filantropi Islam. Dan ditambah induk Filantropi Islam yaitu BAZNAS sehingga totalnya 24. Jenis data yang digunakan dalam penelitian ini adalah data kuantitatif. Sumber data yang digunakan dalam penelitian ini adalah data sekunder. Data sekunder dalam penelitian ini adalah berupa data laporan keungan yang diposting oleh Lembaga Filantropi Islam Nasional melalui website masing-masing.

Akuntabilitas keuangan Lembaga Filantropi Islam ini diukur dengan beberapa indicator yaitu 1) keteraksesan laporan keuangan di website diadaptasi dari Hanifah (2017) dimana akuntabilitas yang efektif tergantung pada akses publik terhadap laporan pertanggungjawaban maupun laporan keuangan yang dapat dibaca dan dipahami dan 2) ketersediaan laporan keuangan di website diadaptasi dari Diani (2016) dimana organisasi publik yang menjalankan asas transparansi dapat dilihat dari ketersediaan informasi yang dapat diakses oleh masyarakat luas dan pihak yang berkepentingan lainnya, selengkapnya ada pada table 1 .

Tabel 1. Indikator Penelitian

\begin{tabular}{|c|c|c|}
\hline Variabel & Indikator & Definisi \\
\hline \multirow[t]{5}{*}{$\begin{array}{l}\text { Akuntabilitas } \\
\text { Keuangan }\end{array}$} & $\begin{array}{l}\text { 1. Keteraksesan laporan keuangan di } \\
\text { website. (Hanifah, 2017) }\end{array}$ & $\begin{array}{lr}\text { tingkat } & \text { kemudahan } \\
\text { pengguna } & \text { dapat }\end{array}$ \\
\hline & $\begin{array}{l}\text { Pengukurannya menggunakan } \\
\text { variabel dummy yaitu, apa bila } \\
\text { Lembaga Filantropi Islam } \\
\text { memiliki website untuk melihat } \\
\text { laporan keungan maka akan diberi } \\
\text { nilai 1 dan jika Lembaga } \\
\text { Filantropi Islam tidak memiliki } \\
\text { website maka akan diberi nilai } 0 .\end{array}$ & $\begin{array}{lr}\text { melihat } & \text { laporan } \\
\text { keuangan } & \text { di } \text { website } \\
\text { Lembaga } & \text { Filantropi } \\
\text { Islam } & \end{array}$ \\
\hline & $\begin{array}{l}\text { 2. Ketersediaan laporan keuangan di } \\
\text { Website berdasarkan PSAK } 109 \\
\text { (Diani, 2016) }\end{array}$ & $\begin{array}{l}\text { Tingkat ketersediaan } \\
\text { dokumen-dokumen } \\
\text { laporan keuangan } \\
\text { secara online di }\end{array}$ \\
\hline & Pengukurannya: & $\begin{array}{lr}\text { website } & \text { Lembaga } \\
\text { Filantropi } & \text { Islam }\end{array}$ \\
\hline & $\begin{array}{l}\text { a. Jika tersedianya laporan posisi } \\
\text { keuangan maka akan berikan } \\
\text { nilai } 1\end{array}$ & berdasarkan PSAK 109 \\
\hline
\end{tabular}




b. Jika tersedianya laporan
perubahan dana maka akan
diberikan nilai 1
c. Jika tersedianya laporan
perubahan asset kelolaan maka
akan diberikan nilai 1
d. Jika tersedianya laporan arus
kas maka akan diberikan nilai
1 Jika tersedianya catatan atas
laporan keuangan maka akan
diberikan nilai 1

Data yang diperoleh dari penelitian ini berupa data sekunder. Tahapan dalam melaksanakan penelitian ini adalah :

1. Pengumpulan data dengan mengunduh laporan keuangan di website masing-masing Lembaga Filantropi Islam.

2. Observasi dan Dokumentasi

a. Mengidentifikasi laporan posisi keuangan

b. Mengidentifikasi laporan aktivitas

c. Mengidentifikasi laporan arus kas

d. Mengidentifikasi catatan atas laporan keuangan

3. Statistik Deskriptif

Statistik deskriptif dalam penelitian ini digunakan untuk menganalisa data dengan cara mendeskripsikan atau menggambarkan data yang telah terkumpul sebagaimana adanya tanpa bermaksud membuat kesimpulan yang berlaku untuk umum atau generalisasi. Termasuk dalam statistik deskriptif antara lain adalah penyajian data melalui tabel, grafik, diagram lingkaran, pictogram, perhitungan modus, median, mean (pengukuran tendensi sentral), perhitungan desil, persentil, perhitungan penyebaran data melalui perhitungan rata-rata dan standar deviasi, perhitungan persentase.

a. Menghitung nilai rata-rata setiap indikator dengan rumus :

$\mathrm{X}=($ Total skor yang didapat / Total Skor Terting gi) X 100\%

b. Hasil perhitungan rata-rata indikator disesuaikan dengan tabel 3.2 (kriteria akuntabilitas keuangan).

Tabel 2. Kriteria Akuntabilitas

\begin{tabular}{|l|l|}
\hline Presentase & Keterangan \\
\hline $0 \%-20 \%$ & Sangat Kurang \\
\hline $21 \%-40 \%$ & Kurang \\
\hline
\end{tabular}


Fitriyah, Pusparini \& Nurabiah: Akuntabilitas Keuangan Lembaga...

\begin{tabular}{|l|l|}
\hline $41 \%-60 \%$ & Cukup \\
\hline $61 \%-80 \%$ & Baik \\
\hline $81 \%-100 \%$ & Sangat Baik \\
\hline
\end{tabular}

Sumber : Riduwan (2013)

\section{HASIL DAN PEMBAHASAN}

Analisis data yang digunakan dalam penelitian ini menggunakan analisis deskriptif kuantitatif dimana jumlah filantropi islam skala nasional ada 23 filantropi. Penelitian ini mencakup dua aspek dalam akuntabiltas keuangan Filantropi Islam yaitu 1) tingkat keteraksesan laporan keuangan 2) tingkat ketersediaan laporan keuangan

Keteraksesan informasi keuangan Filantropi Islam pada website resmi masing - masing lembaga filantropi islam didefinisikan dengan tingkat kemudahan pengguna dapat menemukan dan melihat laporan keuangan di website lembaga filantropi islam. Indikator yang digunakan untuk mengukur keteraksesan informasi keuangan pada website Filantropi Islam, dengan menggunakan variabel dummy yaitu, apabila Filantropi Islam memiliki website untuk melihat laporan keungan maka akan diberi nilai 1 dan jika tidak memiliki website maka akan diberi nilai 0 . Hasil analisis data 24 Filantropi Islam Nasional dapat dilihat pada tabel 3.

Tabel 3. Website Filantropi Islam

\begin{tabular}{|c|c|c|c|}
\hline NO & SAMPEL & WEBSITE & AKSES \\
\hline 1 & $\begin{array}{lll}\begin{array}{l}\text { Badan Amil } \\
\text { (BAZNAS) }\end{array} & \text { Zakat } & \text { Nasional } \\
\end{array}$ & https://baznas.go.id & 1 \\
\hline 2 & Rumah Zakat Indonesia & https://www.rumahzakat.org & 1 \\
\hline 3 & Baitul Maal Muamalat & www.baitulmaalmuamalat.org & 1 \\
\hline 4 & Daarut Tauhid & $\begin{array}{ll}\text { https://dtpeduli.org } & \text { dan } \\
\text { https://dtpeduli.org/swadaya/ }\end{array}$ & 1 \\
\hline 5 & Yatim Mandiri Surabaya & www.yatimmandiri.org & 1 \\
\hline 6 & Dompet Dhuafa Republika & http://www.dompetdhuafa.org & 1 \\
\hline 7 & Nurul Hayat & http://nurulhayat.org & 1 \\
\hline 8 & Inisiatif Zakat Indonesia & http://www.izi.or.id & 1 \\
\hline 9 & Baitul Maal Hidayatullah & www.bmh.or.id & 1 \\
\hline 10 & $\begin{array}{l}\text { Lembaga Amil Zakat Infak } \\
\text { Shodakah NU }\end{array}$ & https://nucare.id & 1 \\
\hline 11 & Global Zakat & www.globalzakat.id & 1 \\
\hline 12 & Pesantren Islam Al Azhar & https://lazalazhar.org & 1 \\
\hline 13 & Dana Sosial Al Falah Surabaya & https://ydsf.org & 1 \\
\hline & Lembaga Manajemen Infaq & & \\
\hline 14 & Ukhuwah Islamiyah & http://lmizakat.org & 1 \\
\hline 15 & $\begin{array}{l}\text { Lembaga Amil Zakat Infak } \\
\text { Shodakah Muhammadiyah }\end{array}$ & https://lazismu.org & 1 \\
\hline 16 & Dewan Dakwah Islamiyah Indonesia & https://www.laznasdewandakwah.or.id & 1 \\
\hline 17 & Perkumpulan Persatuan Islam & https://www.pzu.or.id & 1 \\
\hline 18 & Rumah Yatim Ar Rohman Indonesia & http://rumah-yatim.org & 1 \\
\hline
\end{tabular}




\begin{tabular}{|c|c|c|c|}
\hline NO & SAMPEL & WEBSITE & AKSES \\
\hline 19 & LAZ Yayasan Kesejahteraan Madani & https://yakesma.org & 1 \\
\hline 20 & $\begin{array}{l}\text { LAZ Yayasan Griya Yatim dan } \\
\text { Dhuafa }\end{array}$ & https://griyayatim.com & 1 \\
\hline 21 & $\begin{array}{lcc}\text { LAZ Yayasan } & \text { Daarul } & \text { Quran } \\
\text { Nusantara (PPPA) } & & \\
\end{array}$ & https://pppa.id & 1 \\
\hline 22 & Yayasan Baitul Ummah Banten & http://www.lazisbu.org & 0 \\
\hline 23 & $\begin{array}{l}\begin{array}{l}\text { Yayasan } \\
\text { (AQL) }\end{array} \\
\text { Pusat Peradaban Islam }\end{array}$ & https://laznasaql.org/ & 1 \\
\hline 24 & LAZ Yayasan Mizan Amanah & https://mizanamanah.or.id/ & 1 \\
\hline
\end{tabular}

Berdasarkan tabel 3. menemukan bahwa dari 24 Filantropi Islam Nasional yang sudah ada Surat Keterangan Terdaftar (SKT) hanya satu Filantropi Islam yang tidak bisa dibuka websitenya yaitu Yayasan Baitul Ummah Banten. Dimana websitenya sudah tidak berlaku lagi. Hasil olahan data keteraksesan dari 24 Filantropi Islam Nasional dapat dilihat pada tabel 4

\section{Tabel 4. Keteraksesan Laporan Keuangan Filantropi Islam}

\begin{tabular}{|l|l|l|}
\hline Keterangan & Jumlah & Persentase Keteraksesan \\
\hline Memiliki website & 23 & $95,83 \%$ \\
\hline Tidak memiliki website & 1 & $4,17 \%$ \\
\hline Total & $\mathbf{2 4}$ & $\mathbf{1 0 0 \%}$ \\
\hline
\end{tabular}

Sumber : data olahan (2020)

Dari tabel 4 dapat diketahui bahwa sebanyak 23 atau 95,83\% Filantropi Islam yang memiliki website. Sedangkan hanya 1 atau 4,17\% Filantropi Islam yang tidak memiliki website. Secara keseluruhan, dari total 24 atau 100\% Filantropi Islam dapat disimpulkan bahwa mayoritas Filantropi Islam memiliki website sehingga masyarakat dapat mengakses informasi terkait dengan laporan keuangan Filantropi Islam tersebut. Dan berdasarkan kriteria akuntabilitas yang berada di bab 3 bahwa dari segi keteraksesan sudah sangat akuntabel yaitu di rentang $81 \%-100 \%$.

Tingkat ketersediaan laporan keuangan filantropi islam di Website ini dikukur berdasarkan PSAK 109 dimana ketentuan sebagai berikut : 1) tersedianya laporan posisi keuangan 2) tersedianya laporan perubahan dana 3) tersedianya laporan perubahan asset kelolaan, 4) tersedianya laporan arus kas, dan 5) catatan atas laporan keuangan. Setiap item jika tersedia diberi skor 1 jika tidak tersedia diberi skor 0. Hasil analisis data ketersediaan laporan keuangan di website 24 Filantropi Islam Nasional dapat dilihat pada tabel 5.

Tabel Tabel 5. Ketersediaan Laporan Keuangan di Website 
No Sampel

\begin{tabular}{llll}
\hline & $\begin{array}{l}\text { Badan Amil Zakat Nasional } \\
\text { (BAZNAS) }\end{array}$ & 1 & 1 \\
\hline 2 & Rumah Zakat Indonesia & 1 & 1 \\
\hline 3 & Baitul Maal Muamalat & 1 & 1 \\
\hline 4 & Daarut Tauhid & 1 & 1 \\
\hline 5 & Yatim Mandiri Surabaya & 1 & 1 \\
\hline 6 & Dompet Dhuafa Republika & 1 & 1 \\
\hline 7 & Nurul Hayat & 0 & 0 \\
\hline 8 & Inisiatif Zakat Indonesia & 1 & 1 \\
\hline 9 & Baitul Maal Hidayatullah & 0 & 0 \\
\hline
\end{tabular}

\section{Laporan Laporan Laporan

Posisi Perubahan \\ Arus \\ Kas \\ Kelolaan}

Lembaga Amil Zakat Infak

10 Shodakah NU

11 Global Zakat

12 Pesantren Islam Al Azhar

13 Dana Sosial Al Falah Surabaya

Lembaga Manajemen Infaq

14 Ukhuwah Islamiyah

Lembaga Amil Zakat Infak

15 Shodakah Muhammadiyah

Dewan Dakwah Islamiyah

16 Indonesia

17 Perkumpulan Persatuan Islam 00

Rumah Yatim Ar Rohman

18 Indonesia

LAZ Yayasan Kesejahteraan

19 Madani

1

$\begin{array}{lll}1 & 1\end{array}$

$0 \quad 0$

$0 \quad 0$

$0 \quad 0$

$1 \quad 1$

$0 \quad 0$

0

$0 \quad 0$

$0 \quad 0$

$1 \quad 0$

0

$1 \quad 0$

$0 \quad 0$

0

0

0

0

0

0

0

0

0

1

0

0

1

1

$0 \quad 0$

0

0

Catatan \% a/ LK ketersediaan

$1 \quad 0$

0

\begin{tabular}{l}
80 \\
60 \\
\hline 40 \\
40 \\
80 \\
\hline 80 \\
0 \\
\hline 80 \\
\hline 0 \\
\hline
\end{tabular}

Berdasarkan tabel 5. menemukan bahwa dari 24 Filantropi Islam Nasional yang sudah ada Surat Keterangan Terdaftar (SKT) hanya ada dua Filantropi Islam yang lengkap tersedia laporan keuangannya yaitu Lembaga Amil Zakat Infak Shodakah NU dan LAZ Yayasan Mizan Amanah. Setengah ada yang ada sebagian dan setengahnya tidak tersedia sama sekali. Hasil olahan data 
ketersediaan laporan keuangan di website dari 24 Filantropi Islam Nasional dapat dilihat pada tabel 6.

Tabel 6. Persentase Tingkat Ketersediaan Laporan Keuangan Melalui Website Filantropi Islam

\begin{tabular}{|l|l|l|l}
\hline Keterangan & $\begin{array}{l}\text { Jumlah tidak } \\
\text { tersedia }\end{array}$ & $\begin{array}{l}\text { Jumlah } \\
\text { tersedia }\end{array}$ & $\begin{array}{l}\text { Persentase } \\
\text { Ketersediaan }\end{array}$ \\
\hline Laporan posisi keuangan & 12 & 12 & $50,00 \%$ \\
\hline Laporan perubahan dana & 11 & 13 & $54,17 \%$ \\
\hline $\begin{array}{l}\text { Laporan perubahan asset } \\
\text { kelolaan }\end{array}$ & 17 & 7 & $29,17 \%$ \\
\hline Laporan arus kas & 15 & 9 & $37,50 \%$ \\
\hline $\begin{array}{l}\text { Catatan atas laporan } \\
\text { keuangan }\end{array}$ & 21 & 3 & $12,50 \%$ \\
\hline Total & & $\mathbf{1 0 0 \%}$ \\
\hline
\end{tabular}

Sumber : data olahan (2020)

Dari tabel 6. diketahui bahwa ketersediaan laporan keuangan berbeda-beda setiap temnya. Yang paling banyak yaitu item laporan perubahan dana sebesar 54,17\% dan yang paling sedikit yaitu item catatan atas laporan keuangan sebesar 12,50\%. Dan berdasarkan kriteria akuntabilitas dapat disimpulkan pada tabel 7.

Tabel 7. Kategori Akuntabilitas

\begin{tabular}{|c|c|c|}
\hline Keterangan & \begin{tabular}{|l|} 
Persentase \\
Ketersediaan
\end{tabular} & \begin{tabular}{|l} 
Kategori \\
akuntabilitas \\
keuangan
\end{tabular} \\
\hline Laporan posisi keuangan & $50,00 \%$ & Cukup akuntabel \\
\hline Laporan perubahan dana & $54,17 \%$ & Cukup akuntabel \\
\hline $\begin{array}{l}\text { Laporan perubahan asset } \\
\text { kelolaan }\end{array}$ & $29,17 \%$ & Kurang akuntabel \\
\hline Laporan arus kas & $37,50 \%$ & Kurang akuntabel \\
\hline $\begin{array}{l}\begin{array}{l}\text { Catatan atas laporan } \\
\text { keuangan }\end{array} \\
\end{array}$ & $12,50 \%$ & $\begin{array}{ll}\begin{array}{l}\text { Sangat } \\
\text { akuntabel }\end{array} & \text { kurang } \\
\end{array}$ \\
\hline
\end{tabular}

Sumber : data olahan (2020)

\section{Tingkat Keteraksesan Laporan Keuangan Filantropi Islam}

Berdasarkan data yang ada keteraksesan website filantropi islam nasional sudah sangat bagus dimana sebanyak 23 atau 95,83\% Filantropi Islam yang sudah memiliki website dan gampang untuk diakses atau dibuka. Sedangkan hanya 1 atau 4,17\% Filantropi Islam yang tidak memiliki 
website. Secara keseluruhan, dari total 24 atau 100\% Filantropi Islam menandakan bahwa mayoritas Filantropi Islam memiliki website sehingga masyarakat dapat mengakses informasi terkait dengan laporan keuangan Filantropi Islam tersebut. Dan berdasarkan kriteria akuntabilitas yang berada di bab 3 bahwa dari segi keteraksesan sudah sangat akuntabel.

Website filantropi islam yang menjadi pertanggungjawaban sudah sepenuhnya dapat diakses dengan mudah oleh masyarakat sehingga dalam hal akuntabilitas sudah sangat baik. Tuntutan masyarakat kepada filantropi islam berupa kemudahan masyarakat dalam mengakses informasi yang ada di filatropi islam sudah semakin baik dimana setiap website filantropi islam yang ada sudah sangat gampang untuk dibuka. Konsep akuntabilitas dalam Islam tidak terlepas dari keadilan dan kebenaran. Konsep keadilan menggambarkan dimensi horizontal ajaran Islamyang berhubungan dengan keseluruhan harmoni pada alam semesta atau yang lebih dikenal dengan sunnatullah. Pentingnya keadilan dalam kegiatan ekonomi dikarenakan dalam proses pengambilan keputusan, dibutuhkan informasi yang bermanfaat yaitu informasi yang didapat menggambarkan apa yang telah terjadi dan dalam batas aturan sosial dan perilaku ekonomi yang Islami.

Filantropi islam harus meningkatkan aksesibilitas laporan keuangannya, tidak sekedar menyampaikan ke donatur saja, tetapi juga menyediakan fasilitas kepada masyarakat secara luas agar laporan keuangan dapat diperoleh dengan mudah. Faktor seperti teknologi jaringan dan tenaga ahli dibutuhkan untuk desain website dan akses website yang mudah. Faktor tersebut dapat mempengaruhi tingkat keteraksesan informasi keuangan pada website filatropi islam. Sekalipun filatropi islam mempunyai dorongan yang kuat untuk menyediakan informasi keuangannya sebagai bentuk tekanan dari masyarakat untuk memperoleh informasi, namun apabila tidak didukung oleh infrastruktur jaringan yang memadai, maka kemudahan akses yang diberikan tidak akan maksimal.

Akuntabilitas yang efektif tergantung pada akses publik terhadap laporan pertanggungjawaban maupun laporan keuangan yang dapat dibaca dan dipahami (Hanifah, 2017). Keteraksesan informasi keuangan filatropi islam pada website resmi yang dimiliki, didefinisikan dengan tingkat kemudahan pengguna dapat menemukan dan melihat laporan keuangan di website filatropi islam. Indikator yang digunakan untuk mengukur keteraksesan adalah dengan adanya website yang dimiliki oleh filatropi islam yang nantinya sebagai wadah untuk pelaporan keuangan. Keterakssesan website sebenarnya penting untuk membantu kegiatan-kegiatan filantropi islam, terutama sebagai wadah untuk mempublikasikan laporan keuangan.

Akuntabilitas keteraksesan ini merupakan implikasi dari sharia enterprise theory dimana Allah sebagai sumber amanah utama dan sumber daya yang dimiliki para stakeholders. Shariah enterprise theory mengajarkan bahwa hakekat kepemilikan utama berada pada kekuasaan Allah, sementara manusia hanya diberi hak untuk mengelola (khalifa fil ardhi) (Haryadi, 2010). Manusia diharuskan untuk mempertanggungjawabkan seluruh aktivitas kepada Allah secara vertikal, dan kemudian dijabarkan lagi dalam bentuk pertanggungjawaban secara horizontal kepada umat manusia lain serta pada lingkungan alam. Manusia harus mampu mewujudkan keadilan yang hakiki bagi manusia itu sendiri, manusia lain, masyarakat seluruhnya, alam dan lingkungan serta keadilan bagi Allah sebagai pemilik hakiki di dunia dan akhirat. Oleh karena itu filantropi islam memiliki kewajiban dalam hal mempertanggunjawabkan semua dana-dana yang ada.

Begitu juga dengan implikasi dari teori stewardship bahwasanya manajemen filatropi islam dipandang sebagai pihak yang dapat dipercaya oleh publik untuk melakukan tindakan yang baik dan berguna untuk kepentingan bersama baik secara khusus maupun umum. Lembaga Filantropi Islam akan bekerja sebaik-baiknya untuk kepentingan masyarkat untuk akuntabel dalam transparansi pelaporan keuangan. Filantropi wajib menyediakan informasi publik yang akurat dan 
benar seperti memberikan atau menerbitkan informasi mengenai laporan keuangan yang mudah dijangkau oleh masyarakat.

\section{Tingkat Ketersediaan Laporan Keuangan Filantropi Islam}

Berdasarkan data yang ada ketersediaan laporan keuangan website filantropi islam nasional belum memuaskan dimana jenis laporan keuangan yang paling banyak tersedia hanya 54,1\% yaitu laporan perubahan dana dan itu menandakan akuntabilitas keuangan masih berada di cukup akuntabel. Sedangkan jenis laporan keuangan paling rendah akuntabilitasnya adalah sebesar $12,50 \%$ yaitu catatan atas laporan keuangan dan itu berada di rentang sangat kurang akuntabelnya. Dan yang lainnya berada di posisi cukup akuntabel yaitu laporan posisi keuangan, laporan perubahan asset dan laporan arus kas berada di rentang kurang akuntabel. Artinya untuk tingkat ketersediaan laporan keuangan melalui website, bahwa rata-rata filantropi islam belum melakukan akuntabilitas terkait dengan transparansi laporan keuangan melalui website, khusus untuk laporan perubahan asset, laporan arus kas, dan catatan atas laporan keuangan.

Penyajian laporan keuangan yang tidak lengkap dan tidak aksesibel dapat menurunkan kualitas dari transparansi dan akuntabilitas keuangan (Hanifah, 2017). Ketersediaan laporan keuangan filantropi islam melalui website merupakan hal yang sangat penting dalam memberikan informasi kepada publik. Adanya ketersediaan laporan keuangan tersebut menjadi salah satu indikator bahwa filantropi islam memiliki tingkat akuntabilitas khususnya transparansi yang cukup baik. Artinya bahwa ketersediaan laporan keuangan filantropi islam melalui website bukan hanya sebatas formalitas, tetapi lebih jauh dari itu sebagai bentuk kewajiban filantropi islam dalam memberikan informasi kepada masyarakat. Sebagaimana yang diatur dalam asas transparansi yang sesuai dengan Undang-Undang No. 14 tahun 2008 tentang keterbukaan informasi publik yang mengatur bahwa organisasi publik harus transparan, bertanggung jawab dan lebih berorientasi kepada pelayanan masyarakat. Filantropi islam yang tidak menyediakan laporan keuangan melalui website dapat dianalisis karena laporan keuangan hanya ditujukan kepada donatur. Hal ini terjadi karena filantropi islam memiliki tanggung jawab untuk melaporkan keuangan kepada donatur sebagai pihak yang mendanai program filantropi islam itu sendiri. Sementara di satu sisi masyarakat hanya dianggap sebagai objek dari program sehingga mereka tidak dianggap tidak penting untuk mendapatkan informasi terkait dengan laporan keuangan filantropi islam.

Hal ini bertolak belakang dengan konsep dari sharia enterprise theory dimana mengajarkan bahwa hakekat kepemilikan utama berada pada kekuasaan Allah, sementara manusia hanya diberi hak untuk mengelola (khalifa fil ardhi) (Haryadi, 2010). Manusia diharuskan untuk mempertanggungjawabkan seluruh aktivitas kepada Allah secara vertikal, dan kemudian dijabarkan lagi dalam bentuk pertanggungjawaban secara horizontal kepada umat manusia lain serta pada lingkungan alam. Manusia harus mampu mewujudkan keadilan yang hakiki bagi manusia itu sendiri, manusia lain, masyarakat seluruhnya, alam dan lingkungan serta keadilan bagi Allah sebagai pemilik hakiki di dunia dan akhirat. Oleh karena itu filantropi islam memiliki kewajiban dalam hal mempertanggunjawabkan semua dana-dana yang ada baik bagi donator maupun masyakarat lain. Sama halnya dengan teori stewardship bahwasanya manajemen filatropi islam dipandang sebagai pihak yang dapat dipercaya oleh publik untuk melakukan tindakan yang baik dan berguna untuk kepentingan bersama baik secara khusus maupun umum. Lembaga Filantropi Islam akan bekerja sebaik-baiknya untuk kepentingan masyarkat untuk akuntabel dalam transparansi pelaporan keuangan. Filantropi islam wajib menyediakan informasi publik yang 
Fitriyah, Pusparini \& Nurabiah: Akuntabilitas Keuangan Lembaga...

akurat dan benar seperti memberikan atau menerbitkan informasi mengenai laporan keuangan yang mudah dijangkau oleh masyarakat.

\section{SIMPULAN}

Berdasarkan analisis data sebelumnya, maka dapat disimpulkan hal-hal sebagai berikut:

1. Keteraksesan website filantropi islam nasional sudah sangat akuntabel dimana sebanyak 23 atau 95,83\% Filantropi Islam yang sudah memiliki website dan gampang untuk diakses atau dibuka. Sedangkan hanya 1 atau 4,17\% Filantropi Islam yang tidak memiliki website. Artinya dari total 24 atau 100\% Filantropi Islam nasional menandakan bahwa mayoritas Filantropi Islam memiliki website sehingga masyarakat dapat mengakses informasi terkait dengan laporan keuangan Filantropi Islam tersebut.

2. Ketersediaan laporan keuangan website filantropi islam nasional ada yang sudah cukup akuntanbel yaitu laporan posisi keuangan dan laporan perubahan dana dan ada yang kurang akuntabel yaitu laporan perubahan asset dan laporan arus kas dan sangat kurang akuntabel yaitu catatan atas laporan keuangan. Artinya untuk tingkat ketersediaan laporan keuangan melalui website, bahwa rata-rata filantropi islam belum melakukan akuntabilitas terkait dengan transparansi laporan keuangan melalui website, khusus untuk laporan perubahan asset, laporan arus kas, dan catatan atas laporan keuangan.

Dari kesimpulan yang telah diperoleh dari hasil penelitian ini, maka dapat diberi beberapa saran antara lain:

1. Penelitian ini hanya menggunakan 2 untuk melihat transparansi laporan keuangan melalui website. Penelitian selanjutnya diharapkan mampu menambah indikator-indikator apa saja yang digunakan untuk mengukur tingkat akuntabilitas filantropi islam seperti 1) partisipasi, diman lembaga filantropi LSM harus melibatkan berbagai pihak internal dan eksternal, dalam proses pengambilan keputusan 2) evaluasi, diman ada alat dan prosedur untuk mengevaluasi kinerja lembaga filantropi dan 3) mekanisme pengaduan, dimana lembaga filantropi memungkinkan pemangku kepentingan terutama masyarakat umum mengajukan keluhan terhadap keputusan dan kegiatan-kegiatan yang dilakukan lembaga tersebut.

2. Hasil penelitian ini dapat dijadikan bahan masukan bagi pemerintah sebagai pertimbangan membuat aturan agar keteraksesan dan ketersediaan laporan keuangan dalam website menjadi lebih baik kedepannya dengan memenuhi standar minimal yang ditetapkan

3. Peneliti selanjutnya agar dapat memperpanjang periode penelitian, misalnya lima atau tiga tahun berturut-turut, sehingga akan dapat menggambarkan kondisi keteraksesan dan ketersedian laporan keuangan dalam website lembaga filantropi islam untukjangka waktu yang lebih panjang.

\section{DAFTAR PUSTAKA}

Algadri, Hamid. (1994). Dutch policy against islam and indonesians of arab descent in indonesia. Jakarta: LP3ES, 199, hal. 14.

Athifah., dkk. (2018). Pengaruh akuntabilitas publik dan transparansi laporan keuangan terhadap kepercayaan donatur pada Yayasan PPPA Daarul Qur'an Nusantara . Jurnal Perisai (Islamic Banking And Finance Journal), Vol 2 (1), April 2018, 54-74 ISSN. 2503-3077 
Diani, Rosita, 2016. Analisis Determinan Pelaporan Keuangan di Internet oleh Pemerintah Daerah di Indonesia. (Skripsi Program Akuntansi FEB Universitas Sebelas Maset. Surakarta)

Donaldson dan Davis. (1991). Stewardship theory or agency theory: CEO governance and shareholder returns. Australian Journal Of Management, Vol.16, No.1.

Hanifah, Fika. (2017). Pengaruh kompetisi politik, indeks pembangunan manusia, dan leverage terhadap ketersediaan dan keteraksesan informasi keuangan daerah pada website resmi pemerintah daerah di Indonesia. Skripsi Universitas Negeri Semarang

Haryadi, B. (2010). Political economy of shariah accounting (membangun teori ekonomi politik akuntansi syariah). Malang: Pascasarjana Universitas Brawijaya.

Huda, Nurul, dkk. (2014). Akuntabilitas sebagai sebuah solusi pengelolaan wakaf. Jurnal Akuntansi Multiparadigma, Volume 5, Nomor 3, Desember 2014, Hlm. 485-497

Kusmiati, Mia. (2015). Membangun kesehatan organisasi institusi pendidikan dokter: sebuah transformasi menuju akuntabilitas social. MIMBAR, Vol. 31, No. 1, Juni, pp. 123-134.

Mulawarman, Aji Dedi. (2007). Menggagas neraca syari'ah berbasis maal: kontekstualisasi "kekayaan altruistik islami". The 1st Accounting Conference. FE-UI Depok. 7-9 Nopember.

Nikmatuniayah \& Marliyati. (2015). Akuntabilitas laporan keuangan lembaga amil zakat di kota Semarang. , Jurnal MIMBAR, Vol. 31, No. 2 (Desember, 2015): 485-494

Nurfaida,G. Destya. (2019). Transparansi dan akuntabilitas pengelolaan wakaf masjid agung kauman Semarang. Jurusan Ekonomi Islam Fakultas Ekonomi Dan Bisnis Islam, Universitas Islam Negeri Walisongo Semarang

Nurhasanah, Siti. (2018). Akuntabilitas laporan keuangan lembaga amil zakat dalam memaksimalkan potensi zakat. Akuntabilitas: Jurnal Ilmu Akuntansi Volume 11 (2), 2018: 327 - 348 P-ISSN: 1979-858X; E-ISSN: 2461-1190

Riduwan. (2013). Metode dan teknik menyusun tesis. Bandung: Alfabeta.

Sedarmayanti. (2013). Reformasi administrasi publik, reformasi birokrasi, dan kepemimpinan masa depan. Bandung: PT Refika Aditama.

Sugiyono. (2017). Metode penelitian kuantitatif, kualitatif, dan $r \& d$. Bandung: Alfabeta.

Triyuwono, Iwan. (2002). "Konsep dasar teori akuntansi syari'ah". Seminar Shari'ah Accounting Event 2002. KiAMI-FSI Senat Mahasiswa FEUI. 29 Oktober.

Triyuwono, Iwan. (2007). "Mengangkat ,sing liyan"e untuk formulasi nilai tambah syarieeah. Disajikan dalam Simposium Nasional Akuntansi X Unhas, Makassar, 26-28 Juli 2007

Widyawati,E. Rosmana. (2019). Analisis akuntabilitas pengelolaan wakaf pada badan wakaf Al qur'an Surakarta, Skripsi. Jurusan Akuntansi Syariah Fakultas Ekonomi Dan Bisnis Islam Institut Agama Islam Negeri Surakarta 